\title{
ALGUMAS NOTAS SOBRE A TEORIA GERAL DOS RECURSOS NO CÓDIGO DE PROCESSO CIVIL DE 2015
}

\author{
SOME NOTES ABOUT THE GENERAL THEORY OF RESOURCES IN \\ THE CIVIL PROCESS CODE 2015
}

\author{
Alexandre de Castro Catharina ${ }^{1}$
}

\begin{abstract}
RESUMO
O Código de Processo Civil de 2015 estabeleceu como premissa, dentre outras, instituir um sistema processual assentado num modelo de julgamento que assegure maior previsibilidade, segurança jurídica e isonomia no julgamento de demandas idênticas. Para se alcançar tal objetivo, apostou-se em uma metodologia de julgamento, com escopo em provimentos jurisdicionais vinculativos, nos termos do art. 927, que tem como pressuposto uma densa reformulação da teoria geral dos recursos, de modo a garantir, a um só tempo, a produção decisões judiciais com conteúdo normativo, em sentido forte, como também garantir um adequado procedimento para controle das decisões judiciais proferidas no âmbito do primeiro grau de jurisdição. Neste sentido, pretende-se destacar as principais nuances desta necessária reformulação da teoria geral dos recursos, salientando as principais funções dos tribunais superiores em relação à edição de provimentos jurisdicionais vinculantes, como também em sua atividade jurisdicional tradicional de controle das decisões judiciais pela via recursal. A metodologia de pesquisa empregada no trabalho é o levantamento bibliográfico, de modo a destacar o estado da arte sobre a temática analisada no trabalho.
\end{abstract}

\section{PALAVRAS-CHAVE:}

Teoria geral dos recursos. Provimentos jurisdicionais vinculantes. Segurança jurídica.

\section{ABSTRACT}

The 2015 Code of Civil Procedure established as a premise, among others, to institute a procedural system based on a judgment model that ensures greater predictability, legal certainty and equality in the judgment of identical demands. To achieve this objective, a judgment methodology was used, with scope in binding jurisdictional provisions, pursuant to art. 927, which presupposes a dense reformulation of the general theory of appeals, in order to guarantee, at the same time, the production of judicial decisions with normative content, in a strong sense, as well as to guarantee an adequate procedure to control the judicial decisions handed down in the within the first degree of jurisdiction. In this sense, it is intended to highlight the main nuances of this reformulation of the general theory of appeals, highlighting the main functions of the higher courts in relation to the edition of binding jurisdictional provisions, as well as in

\footnotetext{
${ }^{1}$ Doutor em Sociologia pelo IUPERJ, com ênfase nos Movimentos sociais e a construção dos precedentes judiciais no Brasil. Mestre em Ciências Jurídicas e Sociais pela Universidade Federal Fluminense. Atualmente atua como Advogado e professor de Direito Processual Civil no âmbito da graduação e da pós-graduação. Coordenador do Curso de Direito do Campus Duque de Caxias (2014/2015). Coordenador do Curso de Direito do Campus Nova América, UNESA/ RJ (2015). Coordenador do Grupo de Pesquisa Sociedade Civil, Movimentos Sociais, Cultura Jurídica Processual e Democratização do Processo Civil Brasileiro da Universidade Estácio de Sá/UNESA Campus Nova América/RJ. Pesquisador Produtividade da UNESA (2019). Pós-doutorando em Direito Processual pela Universidade do Estado do Rio de Janeiro - UERJ.
} 
their traditional jurisdictional activity of controlling judicial decisions by appeal. The research methodology used in the work is the bibliographic survey, in order to highlight the state of the art on the theme analyzed in the work.

\section{KEYWORDS:}

General resource theory. Binding jurisdictional provisions. Legal certainty.

\section{INTRODUÇÃO}

O Código de Processo Civil de 2015 apostou num modelo de processo cooperativo, democrático e isonômico no tratamento de casos idênticos ou mesmo no julgamento de demandas repetitivas. Para se atingir tais objetivos, o Código apresenta diversas técnicas processuais como o aprofundamento dos negócios processuais atípicos (art. 190), flexibilização do procedimento (art. 139, VI) ou mesmo saneamento e organização do processo de forma cooperativa (art. $357 \S 3^{\circ}$ ), entre outras técnicas. Dentre as principais inovações propostas pelo novo ordenamento processual, a reformulação do sistema recursal é, sem dúvida, a de maior relevância.

O volume de recursos e ações autônomas de impugnação que tramitam nos diversos segmentos dos Poder Judiciário brasileiro, inclusive nos principais tribunais superiores do país, evidencia a alta taxa de recorribilidade que permeia a prática judiciária do país. Este fenômeno inviabiliza, por si só, a prestação efetiva e célere da tutela jurisdicional adequada. É certo que o sistema recursal não é a única causa da demora e da falta de efetividade da tutela jurisdicional. Há outras variáveis, de ordem estrutural, institucional e demográfica, que concorrem para a morosidade processual. Entretanto, o Código apostou no aprimoramento de técnicas processuais com escopo de dinamizar e racionalizar a administração da justiça, no âmbito dos tribunais, dando maior ênfase à resolução integral do mérito (art. 4 do CPC).

A institucionalização do Incidente de Resolução de Demandas Repetitivas - IRDR (art. 976), a ampliação do escopo da apelação (art. 1.009), a taxatividade do agravo de instrumento (art. 1.015), a fungibilidade entre os recursos excepcionais (arts. 1.032 e 1.033), a reedição e ampliação dos embargos de declaração (art. 1.022) e a remodelagem da dinâmica dos processos nos tribunais são representativos do sistema recursal proposto pelo Código. Em outra 
perspectiva, as ações autônomas de impugnação também foram reestruturadas para se compatibilizar com o sistema recursal empregado. O tratamento infraconstitucional da reclamação e a ampliação do escopo da ação rescisória são inovações normativas importantes neste sentido.

Por outro prisma, o Código empregou um modelo vinculativo de provimento jurisdicionais, cuja principal finalidade é evitar posicionamento diferentes e incompatíveis, no âmbito dos tribunais, sobre a mesma norma jurídica. A denominada jurisprudência uniformizadora ou mesmo a edição de precedentes judiciais ganham destacam neste contexto.

Neste cenário, houve significativa transformação no próprio conceito de recurso e ações autônomas de impugnação como também uma importante redefinição das funções destes institutos em nosso ordenamento processual. Os recursos não mais se limitam à impugnar decisões judiciais. São essenciais na formação de provimentos jurisdicionais vinculativos. As ações autônomas de impugnação não se restringem à impugnação de decisões não mais sujeita a recurso. São utilizadas, também, para controle na aplicação de provimentos jurisdicionais vinculativos.

A teoria geral dos recursos elaborada no período de vigência do CPC/1973 não é suficiente para se compreender e analisar de forma crítica o sistema processual proposto. Se faz necessário uma ampla reformulação da teoria geral dos recursos que contemple, criticamente, o sistema recursal instituído pelo CPC/2015. Não se pretende, neste trabalho, propor algo de tamanha envergadura. Objetiva-se, portanto, destacar, brevemente, algumas inovações normativas no âmbito recursal, seus impactos em nossa processualística e, por fim, destacar a necessidade de se reformular o escopo da teoria geral dos recursos na vigência do CPC/2015.

A metodologia de pesquisa utilizada no trabalho será bibliográfica e, na reflexão sobre alguns institutos, a técnica qualitativa documental lastreada na análise de decisões judiciais proferidas no âmbito dos tribunais superiores. 


\section{PROVIMENTOS JURISDICIONAIS VINCULANTES}

O sistema recursal edificado pelo Código de Processo Civil de 2015 teve como premissa estimular intensa atuação dos tribunais, com a função precípua de proferir decisões que moldem o ordenamento jurídico, considerado objetivamente. Esta função paradigmática dos tribunais é inerente ao sistema recursal proposto pelo Código.

Nesta toada, o art. 926 é categórico ao dispor que os tribunais devem uniformizar sua jurisprudência de modo a mantê-la íntegra, estável e coerente. A jurisprudência uniformizadora, neste sentido, tem como função primeira estabelecer um modelo decisório paradigmático vertical, vinculativo, ordenado por meio dos precedentes judiciais dos tribunais superiores.

Esta perspectiva normativa trouxe à tona a discussão teórica acerca da existência, ou não, de um sistema de precedentes judiciais no CPC/2015. Para determinado segmento da literatura processual há um sistema de precedentes judiciais no Código, instituindo um modelo normativo híbrido (MARINONI, 2017; MITIDIERO, 2017). Contudo, há outro segmento da literatura que sustenta a impossibilidade de se reconhecer no tratamento dado ao tema pelo Código um sistema de precedentes judiciais, tal como foi estruturado nos países que adotaram o Common law. Para esta vertente teórica há um no ordenamento processual um conjunto de provimentos jurisdicionais vinculativos (MENDES, 2017; STRECK, ABBOUD, 2018).

O debate tem como pano de fundo a redação insuficiente do art. 927 do CPC. A redação do referido dispositivo legal determina que os juízes e tribunais deverão observar decisões do STF em controle concentrado, enunciados de súmulas vinculantes, enunciados de súmulas do STF e do STJ, acórdãos do STJ proferidos no julgamento de incidentes de assunção de competência e de resolução de demandas repetitivas, entre outras decisões judiciais, que não guardam identidade técnica ou teórica. Coloca-se, num mesmo patamar normativo, um enunciado de súmula do STJ, um enunciado de súmula vinculante do STF e um acórdão proferido pelo STF em controle concentrado. Por outro lado, exclui os acórdãos proferidos pelo STJ no julgamento de casos subjetivos ${ }^{2}$.

\footnotetext{
${ }^{2}$ O Superior Tribunal de Justiça ao julgar o Recurso em Habeas Corpus nº 97876, em 05/06/2018, fixou importante parâmetro para aplicação das medidas executivas atípicas. Neste julgado, o referido tribunal decidiu que admite-
} 
A despeito deste debate teórico, o Conselho Nacional de Justiça editou a Resolução no 235, de 13 de julho de 2016, através da qual determina a criação dos Núcleos de Gerenciamento de Precedentes, evitando que temas repetitivos ou mesmo pacificados sejam encaminhados aos tribunais superiores. Por sua vez, os tribunais locais estão estruturando seus respectivos Núcleos de Gerenciamento de Precedentes Judiciais de modo a estabelecer um modelo de gestão processual alinhado com os tribunais superiores. Tal movimento demonstra que os tribunais estão se organizando para gerenciar os processos por meio de um modelo de decisões paradigmáticas.

O Poder Judiciário brasileiro está avançando de forma consistente para se consolidar um sistema de decisões judiciais vinculativos. Neste contexto, se faz necessário consolidar um arranjo teórico que contemple as diversas decisões elencadas no art. 927. Caberá, portanto, à teoria geral dos recursos que absorva, também, uma teoria dos precedentes judiciais no Brasil. Thomas da Rosa Bustamante (2012) deu um passo significativo na reflexão acerca da justificação dos precedentes judiciais no Brasil. No mesmo sentido, Marinoni (2010) aprofundou o debate acerca da aplicabilidade de um modelo de precedentes obrigatórios em nossa prática judiciária. Na vigência do CPC/2015 Mitidiero (2017) faz um arranjo interessante ao diferenciar jurisprudência uniformizadora e precedentes judiciais. Nesta linha de análise, as decisões proferidas em Incidentes de Resolução de Demandas Repetitivas se enquadrariam no conceito de jurisprudência uniformizadora e as decisões com forte conteúdo normativo estariam englobadas no conceito de precedentes judiciais.

Não há, ainda, em nossa processualística, um consenso acerca dos principais conceitos ou mesmos elementos básicos acerca de uma teoria geral dos recursos e dos precedentes judiciais na vigência do CPC/2015. Não se sabe ao certo, ainda, se há espaço para uma teoria geral dos recursos vez que densa mudança metodológica e paradigmática no que tange à formação e controle das decisões judiciais. O CPC/2015 sugere uma sólida teoria da decisão judiciais e seus mecanismos de controle.

\footnotetext{
se a retenção de passaporte, dentre outras medidas atípicas desde que a) se esgote os meios executivos típicos; b) seja feita ponderação sobre a proporcionalidade, adequação e necessidade da medida, e c) seja observado o contraditório pleno. Trata-se de importante precedente judicial que balizou, em alguma medida, a aplicação das medidas executivas atípicas. À luz do art. 927 esta decisão judicial, embora tenha conteúdo normativo forte, não pode ser considerado precedente judicial ou provimento jurisdicional vinculativo.
} 
Partindo desta premissa, esta teoria da decisão judicial precisa de um arcabouço teórico sólido que permita fazer uma leitura do art. 927, estabelecendo categorias e conceitos bem estruturados de modo a viabilizar a compreensão adequada acerca dos precedentes judiciais no Brasil. Em nosso sentir o art. 927 trata de jurisprudência uniformizadora (julgamento de recursos repetitivos no âmbito do STJ), provimentos jurisdicionais vinculantes (julgamento de incidentes de demandas repetitivas), precedentes judiciais (acórdãos do STF em sede de controle concentrado) e acórdãos do STJ, ainda que subjetivos, que tenha forte conteúdo normativo, mesmo que não esteja incluído no rol do referido dispositivo legal.

Esta distinção conceitual entre jurisprudência uniformizadora, provimentos jurisdicionais vinculantes e precedentes judiciais é fundamental no Brasil. A padronização decisória em nosso país se estabeleceu com ênfase na administração da justiça e na redução da taxa de recorribilidade. Não houve, em nossa história judiciária uma preocupação coma edição de decisões judiciais com conteúdo normativo forte para resolver os denominados casos difíceis (DWORKIN, 2010). Em nossa cultura jurídica processual, fortemente vinculada ao modelo de julgamento do civil law, a jurisprudência foi concebida como elemento persuasivo, de um lado, e, por outro, como mecanismo de redução de recursos e padronização decisória, principalmente no período posterior à Emenda Constitucional no 45 de $2004^{3}$.

A vigência do Código de Processo Civil de 2015 e as dificuldades práticas e conceituais que se evidenciaram em sua aplicação no período inicial, principalmente no que concerne a compreensão dos precedentes judiciais vem demandando da doutrina processual a elaboração de uma teoria decisão que contemple os conceitos oriundos da teoria geral dos recursos acerca do mérito recursal, requisitos de admissibilidade, mas que contemple, também, uma teoria dos precedentes judiciais estruturada a partir de nossa cultura jurídica.

\footnotetext{
${ }^{33}$ A Emenda Constitucional nº 45 de 2004 inseriu em nosso ordenamento jurídico institutos importantes como a súmula vinculante e a repercussão geral.
} 


\section{TRATAMENTO NORMATIVOS DOS RECURSOS E AÇÕES AUTÔNOMAS DE IMPUGNAÇÃO NO CPC/2015}

Algumas alterações profundas foram realizadas no tratamento normativo dos recursos e das ações autônomas de impugnação. A dinâmica dos processos nos tribunais foi sensivelmente modificada ${ }^{4}$. Por sua vez, o tratamento infraconstitucional da reclamação, para maior controle da autoridade das decisões dos tribunais superiores, e ampliação do escopo da ação rescisória sugerem a necessidade de reformulação da teoria geral dos recursos erigida na vigência do CPC/1973.

As inovações, embora pontuais, denotam um modelo de processo voltado para a efetividade e adequação da tutela jurisdicional, em que os princípios da segurança jurídica e da primazia do julgamento do mérito são os principais vetores axiológico. Para dimensionar adequadamente a mudança de paradigma em nosso sistema recursal passemos à análise mais detida das principais inovações.

\subsection{Do aproveitamento do recurso interposto inadequadamente}

$\mathrm{O}$ art. 932, parágrafo único, determina que o relator somente inadmitirá o recurso interposto após a concessão de prazo de 05 (cinco) dias para correção do vício ou complementação da documentação exigível. Tal regra permite ao recorrente corrigir eventuais vícios, viabilizando o julgamento do recurso interposto em desalinho com a forma prescrita no código.

Essa regra permite, inclusive, que o agravante, no prazo de 05 dias, complemente as cópias obrigatórias, elencadas no art. 1.017, I, conforme dispõe expressamente o parágrafo $3^{\circ}$ do mesmo dispositivo legal. Nota-se, portanto, que se trata de uma metodologia de solução de

\footnotetext{
${ }^{4}$ Adriano Moura da Fonseca Pinto (2020) destaca, em interessante estudo empírico sobre a dinâmica do processo nos Tribunais, que a exigência de fundamentação estruturada das decisões judiciais pelo Código de Processo Civil de 2015 vem contribuindo para o estabelecimento de um modelo decisório alinhado com os precedentes judiciais dos Tribunais superiores, em áreas sensíveis como o Direito do Consumidor, onde a técnica da decisão monocrática tem sido relevante para racionalizar a atividade judiciária.
} 
conflitos que privilegia o julgamento de mérito do recurso, eliminando do sistema recursal a inadmissibilidade inócua de recursos interpostos inadequadamente, do ponto de vista formal, mas que podem viabilizar a análise da questão de fundo.

Em verdade, não se trata de fungibilidade recursal, mas sim da ampliação do princípio da instrumentalidade das formas para o âmbito recursal. Importante destacar que o código não privilegiou o descuido ou despreparo dos operadores do direito na interposição de recursos, ao contrário, deu força normativa ao princípio do acesso à ordem jurídica justa, que tem como corolário garantir não somente o acesso ao sistema de justiça, mas, principalmente, alcançar a decisão de mérito da questão submetida ao Poder Judiciário. Parece-nos ser essa a melhor interpretação do art. $4^{\circ}$ do CPC/2015.

Neste sentido, trata-se de um postulado voltado para a instrumentalidade recursal que norteia admissibilidade de todos os recursos regidos pelo art. 994 do CPC/2015. Neste contexto, o Código de Processo Civil de 2015 se contrapõe a certa cultura jurídica processual que se acumulou através da edição de diversos precedentes voltados para inadmissão de recursos, denominada pela doutrina como jurisprudência defensiva ${ }^{5}$. Superou-se, por assim dizer, o excesso de formalismo que perpassou a prática judiciária brasileira nas últimas décadas.

\subsection{Da possibilidade de adequação do preparo}

É notório que uma das principais causas da inadmissão de recursos é o recolhimento incorreto do preparo. A teoria geral dos recursos tradicional classifica o preparo como requisito extrínseco dos recursos. O CPC/ 1973 admitia a complementação do preparo insuficiente no prazo de 05 dias, conforme dispunha o art. 511, $\S 2^{\circ}$. No entanto, a regra somente era aplicada nos casos de insuficiência, sendo declarado deserto os recursos que, por alguma razão, não fora recolhido.

O CPC/2015 estabeleceu um regime amplo no sentido de viabilizar a correção de vícios ou insuficiência do preparo optando por evitar a inadmissibilidade de recursos pela ausência

\footnotetext{
${ }^{5}$ Como exemplo pode-se citar o verbete da súmula 418 do STJ, que inadmitia como intempestivo o recurso interposto antes do prazo. Tal entendimento foi superado pela regra do art. $218, \S 4^{\circ}$ do CPC/2015.
} 
desse requisito recursal. $\mathrm{O}$ art. 1.007, $\S 2^{\circ}$ confere prazo de 05 dias para complementação do preparo insuficiente. Neste particular não há inovação em nossa processualística.

Entretanto, a inovação decorre da regra do parágrafo $4^{\circ}$ do mesmo dispositivo legal, que permite o recolhimento integral do preparo no prazo de 05 dias, nos casos em que não houver comprovação de seu recolhimento no ato da interposição. Trata-se de regra importante em nossa sistemática que tem como escopo maior alcançar o enfrentamento do mérito recursal como premissa maior da atividade judiciária.

O Código permite, ainda, ao recorrente sanar vícios decorrentes de preenchimento indevido da guia de custas, conforme dispõe o art. 1.007, § $7^{\circ}$, no prazo de 05 dias. Essas regras, interpretadas sistematicamente, nos conduzem à compreensão de que o Código de Processo Civil de 2015 estabeleceu como eixo transversal a instrumentalidade das formas estabelecendo como regra instransponível o julgamento do mérito dos recursos.

O regime do preparo no código revogado permitia que questões jurídicas graves e prementes não fossem apreciadas devido a questões secundárias como recolhimento das custas ou preenchimento indevido das guias. Essa prática judiciária não se coaduna com as garantias constitucionais processuais que foram incorporadas pelo novo código em suas normas fundamentais ${ }^{6}$.

\subsection{Da sistemática dos embargos de declaração}

Dentre os recursos enumerados em nossa processualística civil os embargos de declaração foram os que mais sofreram alterações. Em verdade, as alterações no regime dos embargos de declaração decorreram da incorporação de conceitos doutrinários e precedentes judiciais sobre a temática, contribuindo para ampliar e aprimorar o escopo desse importante

\footnotetext{
${ }^{6}$ Marinoni (2015) sustenta com clareza sobre a irradiação dos princípios constitucionais no processo civil ao dizer que: tendo em conta o caráter instrumental do processo, que serve precipuamente para a tutela dos direitos, eventuais equívocos na sai condução devem ser sobrelevados, sempre que possível, para que o processo possa alcançar a sua finalidade. Repugna ao Estado Constitucional que o direito material venha a soçobrar em face do uso inadequada do processo. Assim como o "erro de forma do processo" acarreta unicamente a "anulação dos atos que não possam ser aproveitados" (art.283), também o erro na interposição de terminado recurso só deve conduzir ao seu não conhecimento acaso não possa de modo algum ser conhecido (p. 514).
} 
recurso, cuja finalidade é corrigir e integrar decisões judiciais. Destacaremos os principais aspectos dos embargos de declaração.

O primeiro aspecto diz respeito à conversão dos embargos de declaração em agravo interno nos termos no art. 1.024, $\S 3^{\circ}$ do CPC. Em verdade, o recebimento dos embargos de declaração como agravo interno já constitui prática de alguns Tribunais brasileiros, em homenagem ao princípio da instrumentalidade, compreendido em seu sentido lato. O código, portanto, tornou essa prática regra geral, mas avançou no sentido de determinar que, nesses casos, o órgão deverá intimar o recorrente para, no prazo de 05 dias, complementar suas razões recursais.

A finalidade da regra é impedir que os embargos de declaração sejam admitidos como agravo interno mas no mérito seja negado provimento por insuficiência de fundamentação. A imposição legal é acertada considerando que os embargos de declaração possuem fundamentação vinculada, o que impede maiores alegações e fundamentos que não se enquadrem nas hipóteses de cabimento dispostas no art. 1.022. A regra, entretanto, decorre do instrumentalismo recursal que visa possibilitar a apreciação adequada do mérito.

O segundo aspecto concerne à dispensa da ratificação do recurso interposto pelo embargado, conforme dispõe o art. $1.024, \S \S^{\circ}$ e $5^{\circ}$. Destarte, caso haja oposição de embargos de declaração por uma parte e interposição de apelação pela outra o processamento da apelação será interrompido (art. 1.026). No entanto, após o julgamento dos embargos de declaração o apelante está dispensado de ratificar o recurso previamente interposto, o que constitui avanço no que diz respeito à instrumentalidade recursal.

O CPC/2015, portanto, estabelece, neste particular, procedimentos distintos que são definidos a partir do resultado do julgamento dos embargos de declaração. Se os embargos forem rejeitados, o recurso interposto pela outra parte antes da publicação do julgamento dos embargos será processado independente de ratificação (art. 1.024, §5º ). Caso os embargos forem acolhidos e alterarem o conteúdo da decisão, a parte que interpôs apelação será intimada para alterar suas razões recursais no limite da modificação realizada pelo julgador, no prazo de 15 dias (art. 1.024, $\S 4^{\circ}$ ). Sem dúvida, trata-se de importante avanço no que tange ao aproveitamento dos atos recursais praticados. 
Importante registrar que o Superior Tribunal de Justiça, no período da vacatio legis do CPC/2015, sinalizou (overruling), ao julgar o REsp 1.129.215-DF, no sentido da aplicabilidade parcial da Súmula $418^{7}$, limitando-se a necessidade de ratificação somente nas hipóteses de modificação do julgado. No entanto, o avanço interpretativo deste tribunal superior ainda admite a eficácia da referida súmula determinando a ratificação nos casos em que haja modificação do julgado. Parece-nos, numa primeira análise, que a decisão ainda não está em

\section{${ }^{7}$ DIREITO PROCESSUAL CIVIL. DESNECESSIDADE DE RATIFICAÇÃO DO RECURSO INTERPOSTO NA PENDÊNCIA DE JULGAMENTO DE EMBARGOS DECLARATÓRIOS.} Não é necessária a ratificação do recurso interposto na pendência de julgamento de embargos de declaração quando, pelo julgamento dos aclaratórios, não houver modificação do jugado embargado. A Súmula 418 do STJ prevê ser "inadmissível o recurso especial interposto antes da publicação do acórdão dos embargos de declaração, sem posterior ratificação". A despeito da referida orientação sumular, o reconhecimento da (in)tempestividade do recurso prematuro por ter sido interposto antes da publicação do acórdão recorrido ou antes da decisão definitiva dos embargos de declaração - e que não venha a ser ratificado - foi objeto de entendimentos diversos tanto no âmbito do STJ como do STF, ora se admitindo, ora não se conhecendo do recurso. Ao que parece, diante da notória divergência, considerando-se a interpretação teleológica e a hermenêutica processual, sempre em busca de conferir concretude aos princípios da justiça e do bem comum, mostra-se mais razoável e consentâneo com os ditames atuais o entendimento que busca privilegiar o mérito do recurso, o acesso à justiça (art. $5^{\circ}, \mathrm{XXXV}$, da $\mathrm{CF}$ ), dando prevalência à solução do direito material em litígio, atendendo a melhor dogmática na apreciação dos requisitos de admissibilidade recursais, afastando o formalismo interpretativo para conferir efetividade aos princípios constitucionais responsáveis pelos valores mais caros à sociedade. Nesse contexto, a celeuma surge exatamente quando se impõe ao litigante que interpôs recurso principal, na pendência de julgamento de embargos declaratórios, o ônus da ratificação daquele recurso, mesmo que seja mantida integralmente a decisão que o originou. É que a parte recorrente (recurso principal) não poderá interpor novo recurso, não obstante a reabertura de prazo pelo julgamento dos embargos, uma vez constatada a preclusão consumativa. Em verdade, só parece possível pensar na obrigatoriedade de ratificação - rectius complementação - do recurso prematuramente interposto para que possa também alcançar, por meio de razões adicionais, a parte do acórdão atingida pelos efeitos modificativos e/ou infringentes dos embargos declaratórios. Aliás, trata-se de garantia processual da parte que já recorreu. Deveras, é autorizado ao recorrente que já tenha interposto o recurso principal complementar as razões de seu recurso, caso haja integração ou alteração do julgado objeto de aclaratórios acolhidos, aduzindo novos fundamentos no tocante à parcela da decisão que foi modificada. Porém, ele não poderá apresentar novo recurso nem se valer da faculdade do aditamento se não houver alteração da sentença ou acórdão, porquanto já operada, de outra parte, a preclusão consumativa - o direito de recorrer já foi exercido. Esse entendimento é consentâneo com a jurisprudência do STJ (REsp 950.522-PR, Quarta Turma, DJe 8/2/2010). Assim sendo, não havendo alteração da decisão pelos embargos de declaração, deve haver o processamento normal do recurso (principal), que não poderá mais ser alterado. Esse entendimento é coerente com o fluxo lógico-processual, com a celeridade e com a razoabilidade, além de estar a favor do acesso à justiça e em consonância com o previsto no art. 1.024, § $5^{\circ}$, do novo CPC. Dessarte, seguindo toda essa linha de raciocínio, o STF proclamou, recentemente, posicionamento no sentido de superar a obrigatoriedade de ratificação (RE 680.371 AgR-SP, Primeira Turma, DJe 16/9/2013). Ademais, no tocante aos recursos extraordinários, que exigem o esgotamento de instância (Súmula 281 do STF), não há falar que a interposição de recurso antes do advento do julgamento dos embargos de declaração não seria apta a tal contendo. Isso porque os aclaratórios não constituem requisito para a interposição dos recursos excepcionais, não havendo falar em esgotamento das vias recursais, uma vez que se trata de remédio processual facultativo para corrigir ou esclarecer o provimento jurisdicional. Com efeito, a referida exigência advém do fato de que os recursos extraordinários não podem ser exercidos per saltum, só sendo desafiados por decisão de última ou única instância. Entender de forma diversa seria o mesmo que afirmar que sempre e em qualquer circunstância os litigantes teriam que opor embargos declaratórios contra acórdão suscetível de recurso de natureza extraordinária. Aliás, o efeito interruptivo dos embargos, previsto no art. 538 do CPC, só suporta interpretação benéfica, não podendo importar em prejuízo para os contendores. Portanto, a única interpretação cabível para o enunciado da Súmula 418 do STJ é no sentido de que o ônus da ratificação do recurso interposto na pendência de julgamento de embargos declaratórios apenas existe quando houver modificação do julgado embargado. REsp 1.129.215-DF, Rel. Min. Luis Felipe Salomão, julgado em 16/9/2015, DJe 3/11/2015. 
perfeito alinhamento com CPC/2015, considerando que o código determina tão somente o direito da parte de complementar, no prazo de 15 dias, suas razões recursais.

Neste sentido, ao se interpretar, contrario sensu, a regra do art. $1.024, \S 4^{\circ}$, concluímos pela admissão do recurso, mesmo nos casos em que a decisão tenha sofrido modificação e o recorrente não tenho complementado suas razões recursais. Tal interpretação literal, por si só, conduz a conclusão da total ineficácia da Súmula 418, mesmo com a nova interpretação atribuída pelo STJ no julgado mencionado acima.

O terceiro e último aspecto está relacionado com os embargos de declaração para fins de pré-questionamento. A ausência de pré-questionamento ${ }^{8}$ constitui, sem dúvida, uma das maiores causas de inadmissibilidade dos recursos excepcionais. O art. 1.025 do CPC superou esse obstáculo formal ao considerar incluídos no acórdão recorrido os elementos que o embargante suscitou, mesmo nos casos em que os embargos são rejeitados pelo órgão julgador. No entanto, a regra somente será aplicada nos casos em que o tribunal superior considerar como existentes os fundamentos veiculados nos embargos declaratórios.

A regra é fundamental para se evitar arbitrariedades no julgamento dos embargos com fins de pré-questionamento que, em alguns casos, são rejeitados sob o fundamento de que não há omissão ou obscuridade inviabilizando o acesso do embargante aos tribunais superiores por ausência de tal requisito. Não há dúvida de que o mencionado dispositivo reduzirá arbitrariedades e terá, como consequência, a redução da incidência de aplicação de multa por embargos protelatórios ${ }^{9}$. Em nosso entendimento, o novo regramento dos embargos de declaração evidencia o postulado do instrumentalismo recursal muito bem dimensionado pelo $\mathrm{CPC} / 2015$.

Outro dado digno de nota, nesta temática, é a superação da Súmula $320^{10}$ do Superior Tribunal de Justiça pelo art. 941, $\S 3^{\circ}$. O mencionado dispositivo dispõe que o voto vencido integrará o acórdão, inclusive para fins de pré-questionamento. Assim, mesmo que a questão

\footnotetext{
${ }^{8}$ Pré-questionar significa discutir nas instâncias inferiores a questão federal ou constitucional que se pretende levar, pela via dos recursos excepcionais, aos Tribunais superiores.

${ }^{9}$ A rejeição dos embargos declaratórios com fins de pré-questionamento enseja a oposição de novos embargos com a finalidade de cumprir o requisito. No entanto, a reiteração de embargos acarreta a aplicação multa, que foi majorada no CPC/2015, dificultando o acesso do embargante aos tribunais superiores. Essa regra garante o acesso aos tribunais superiores mesmo nos casos de arbitrariedades dos tribunais locais.

10 "A questão federal somente ventilada no voto vencido não atende ao requisito do prequestionamento".
} 
(constitucional ou federal) tenha sido ventilada somente no voto vencido e os embargos de declaração forem rejeitados o requisito do pré-questionamento estará presente. Trata-se de inovação que pretende superar uma cultura jurídica e judiciária fundada em ampla jurisprudência defensiva. Essas inovações evidenciam a postura metodológica do Código assentada num instrumentalismo recursal.

\subsection{Da conversão do recurso extraordinário em recurso especial e vice-versa}

Os recursos excepcionais são instrumentos processuais de grande relevo no modelo de padronização decisória que se pretende implementar normativamente (THEODORO JUNIOR, NUNES, BAHIA, PEDRON, 2015). Para alcançar esta finalidade, os recursos excepcionais foram objeto de diversas inovações no Código de Processo Civil de 2016. A inovação que será abordada nessa reflexão diz respeito à conversão do recurso extraordinário em recurso especial e vice-versa. A instrumentalidade recursal mencionada está disposta nos arts. 1.032 e 1.033.

Segundo a norma do art. 1.032, se o relator do recurso especial no Superior Tribunal de Justiça entender que a matéria impugnada versa sobre tema constitucional deverá conceder prazo para que o recorrente demonstre a respectiva repercussão geral (requisito específico do recurso extraordinário) e, após o cumprimento do requisito, o recurso será remetido ao Supremo Tribunal Federal. A regra do art. 1.033 é similar. Caso o relator do recurso extraordinário entender que a violação ao texto constitucional é reflexa, remeterá o recurso para o Superior Tribunal de Justiça que deverá proceder ao julgamento do respectivo recurso.

A regra é, em nosso sentir, inovadora e voltada para aproveitamento do recurso excepcional interposto viabilizando o acesso às Cortes superiores, principalmente se considerarmos a objetivação dos recursos especial e extraordinário aprofundada pela CPC/2015. 


\subsection{A importância da ação rescisória e da reclamação no controle dos precedentes judiciais}

O Código deu novos contornos às ações autônomas de impugnação. Neste contexto, a reclamação (art. 988) e ação rescisória (art. 966) não se limitam a tutelar direitos subjetivos das partes. Estas ações autônomas de impugnação têm, dentre seus escopos, o controle na aplicação dos precedentes judiciais e provimentos jurisdicionais pelos tribunais.

$\mathrm{O}$ art. 966, $\S 5^{\circ}$ do CPC, com redação inserida pela Lei $n^{\circ} 13.256 / 2016$, dispõe que é cabível ação rescisória contra decisão baseada em enunciado de súmula ou em acórdão proferido em julgamento de recursos repetitivos sem considerar existência de distinção entre a questão discutida no processo e o padrão decisório que lhe deu fundamento. $\mathrm{O}$ critério de distinção (distinguishing) é um importante método de controle na aplicação dos precedentes judiciais nos países que adotam o Common law e este papel foi atribuído à ação rescisória no processo civil brasileiro ${ }^{11}$.

Por sua vez, a reclamação teve, também, seu escopo ampliado. O art. 988, §4º , caberá reclamação quando houver aplicação indevida de súmulas vinculantes e acórdãos proferidas em controle concentrado da constitucionalidade (art. 988, III) e nos casos de aplicação incorreta de tese jurídica fixada em julgamento de incidente de assunção de competência e no julgamento de incidente de resolução de demanda repetitiva (art. 988, IV) ${ }^{12}$.

Decerto, o Código reformulou o tratamento normativo das ações autônomas de impugnação mencionadas acima dando destaque para um certo hibridismos à estes instrumentos processuais. Estas ações podem tutelar, em uma dimensão, interesses subjetivos das partes envolvidas em um determinado litígio, como também podem ser utilizadas, em outra dimensão, para aprimorar o modelo de precedentes judiciais proposto Código.

\footnotetext{
${ }^{11}$ Camilo Zufelato e Caio Gracco Pinheiro Dias (2020) tratam desta nova roupagem da ação rescisória ao analisar a aplicação inadequada dos precedentes judiciais em sede de tutela coletiva. No caso concreto analisado no trabalho, a ação rescisória foi proposta contra decisão do Superior Tribunal de Justiça que ampliou, indevidamente, a extensão da ratio decidendi de um determinado precedente judicial. A casuística demonstra a aplicabilidade e eficácia da ação rescisória como meio de controle dos precedentes judiciais.

12 O Superior Tribunal de Justiça reforçou este entendimento acerca da função da Reclamação, na hipótese do art. 988, IV, no julgamento do Reclamação n $36.376-$ SP.
} 


\section{POR UMA TEORIA GERAL DOS RECURSOS NO CPC/2015}

A análise panorâmica do tratamento normativo dado aos recursos e as ações autônomas de impugnação sugerem a necessidade de se reconstruir a teoria geral dos recursos. Os principais conceitos elaborados pela teoria dos recursos na vigência do CPC/1973 tinham como objeto análise remédios processuais que tinham como finalidade primeira promover a revisão e controle das decisões judiciais de modo assegurar o duplo grau de jurisdição. Esta não é mais a função dos recursos e das ações autônomas de impugnação.

O modelo decisório proposto pela Código redimensionou as funções dos recursos e das ações autônomas de impugnação como instrumentos propulsores dos precedentes judiciais, como também mecanismos de controle em sua aplicação (distinguishing) e de superação dos precedentes judiciais que não mais atenda à ordem jurídica vigente (overruling). É certo que tais técnicas de controle e aplicação dos precedentes judiciais não coaduna com a cultura jurídica processual brasileira. Com efeito, a reconstrução da teoria geral dos recursos, com ênfase numa ampla teoria da decisão judicial, contribuirá para conformação de um processo decisório mais amplo, inclusivo e democrático.

Esta reconstrução da teoria geral dos recursos deve observar, pelo menos, 03 linhas de análise, quais sejam: a) estabelecer elementos para uma teoria dos precedentes judiciais a partir do modelo decisório brasileiro; b) redefinir conceitualmente as funções dos recursos e das ações autônomas no modelo decisório proposto pelo Código e, por fim, c) assegurar mecanismos de participação e democratização dos processos decisórios com tendência a originar precedentes judiciais com força vinculante.

A eficácia de um instituto jurídico depende, em certa medida, de sua compatibilidade com a cultura jurídica que está inserida (SOARES, COUTO, COSTA, 2018). O transplante de um instituto processual conformado em uma determinada cultura jurídica não produz os mesmos efeitos quando aplicado de forma acrítica em outra cultura jurídica. Não há no Brasil uma cultura jurídica ${ }^{13}$ estruturada num modelo de julgamento assentado em precedentes

\footnotetext{
${ }^{13}$ Fernanda Duarte e Rafael Iorio (2011) destacam, em interessante pesquisa empírica inspirada na metodologia da observação participante, as nuances da cultura jurídica processual que informa a prática judiciária brasileira e se manifesta na aplicação dos mais variados institutos da processualística brasileira.
} 
judiciais. Em outro sentido, a jurisprudência e as súmulas no direito brasileiro foram assimiladas como instrumentos de administração da justiça e racionalização da atividade judicial sem maiores preocupações com elaboração de conceitos no âmbito da teoria do processo. O resquício desta cultura jurídica se torna manifesto na própria redação insuficiente do art. 927.

Por essa razão, instituir, pela via de uma reconstrução da teoria geral dos recursos, com ênfase na teoria da decisão judicial, uma classificação adequada com definição de graus e intensidade de provimentos jurisdicionais se faz premente para impedir que o modelo decisório proposto pelo Código seja apreendido somente pela ótica da gestão de processos pelo Poder Judiciário. Há uma importante dimensão da tutela jurisdicional efetiva, adequada relacionada com o acesso à ordem jurídica justa que pode, também, ser assegurada por um sistema de precedentes judiciais devidamente fundamentado e justificado.

Uma teoria da decisão judicial bem estruturada permite, inclusive, superar lacunas e deficiências legislativas. É neste contexto que se insere a necessidade de se estabelecer uma teoria dos precedentes judiciais a partir da cultura jurídica brasileira. Esta teoria deve harmonizar padrões decisórios distintos como jurisprudência uniformizadora, provimentos jurisdicionais vinculantes e precedentes judiciais.

É imperioso superar a clivagem teórica quanto a existência ou não de um sistema de precedentes judiciais no CPC. Em sociedades complexas e desiguais como a brasileira um sistema de precedentes judiciais é fundamental para corrigir, em alguns casos, a leniência do parlamento $^{14}$. O julgamento da ADPF n 132 (união homoafetiva) e da ADPF no 186 (cotas raciais) são exemplos contundes neste sentido.

Não há como sustentar que o Código contempla um único modelo decisório. Evidente que não. Coexistem, no mesmo ordenamento processual, decisões judiciais que funcionam como jurisprudência uniformizadora, que necessita de um grau mínimo de participação e

\footnotetext{
${ }^{14}$ Para Maria Inês da Silva e Luciana Drimel Dias (2020) o modelo de precedentes judiciais, no Brasil, pode contribuir para formação de decisões mais igualitárias e pode, portanto, contribuir para efetivação de maior justiça social no direito brasileiro.
} 
democratização. Podemos citar como exemplo as decisões dos Órgãos Especiais dos tribunais locais ${ }^{15}$.

Em outra dimensão, há decisões judiciais que possuem contornos de provimentos jurisdicionais vinculativos, por meio do qual se fixam teses sobre demandas seriais ou repetitivas. As teses fixadas em incidentes de resoluções de demandas repetitivas se enquadram nesta categoria. Há, por fim, decisões judiciais que contém conteúdo normativo em sentido forte, que trazem previsibilidade e segurança jurídica sobre questões de fato não contempladas pelo legislador, como o reconhecimento da união homoafetiva. Neste caso, podemos afirmar que trata-se de um precedente judicial. Esta é a primeira linha de análise que deve ser observada numa reconstrução de uma teoria geral dos recursos na vigência do CPC/2015.

A segunda linha de análise se relaciona com a redefiniçãa dos conceitos de recursos e ações autônomas de impugnação. Estes instrumentos processuais não são mais estanques. Os recursos e as ações autônomas de impugnação integram um sistema recursal mais amplo e exercem funções híbridas como controle das decisões judiciais, mais especificamente no que diz respeito à tutela subjetiva das partes envolvidas na relação processual. Em outra concepção, os recursos e as ações autônomas agregam novas funções como formação de jurisprudência uniformizadora, provimentos jurisdicionais vinculantes e precedentes judiciais (THEODOR JUNIOR, NUNES, BAHIA, PEDRON, 2015, p. 332), mas também de controle e revisão de precedentes judiciais, como se depreende do novo desenho da reclamação e da ação rescisória.

As inovações acerca dos requisitos de admissibilidade dos recursos, a fungibilidade entre os recursos excepcionais, o redimensionamento dos embargos de declaração, representam um instrumentalismo recursal denso de modo a fortalecer o modelo decisório vinculativo instituído pelo Código. Conquanto, para que esta função híbrida dos recursos e das ações autônomas de impugnação alcancem plena eficácia, se faz iminente uma reformulação da teoria geral dos recursos de modo a contemplar, do ponto de vista teórico, estas funções.

A terceira linha de análise concerne à democratização dos processos nos tribunais. Não se pode conceber um modelo decisório normativo sem assegurar ampla participação e democratização do processo decisório (CATHARINA, 2015). A ampliação do espectro de atuação do amicus curiae (art. 138), a possibilidade de realização de audiência pública no

${ }^{15}$ Daniel Mitidiero (2017) sugere esta compreensão acerca da função dos tribunais locais. 
julgamento de recursos excecionais (art. 1.038, II) representam importante democratização do processo decisório, essencial para edição de precedentes judiciais ou mesmos provimentos jurisdicionais vinculativos em sociedades desiguais como o Brasil. Pode se dizer, que o modelo dialógico, participativo e democrático proposto por Habermas (2003), guardadas as devidas proporções, estão contempladas, do ponto de vista normativo, no modelo democrático de processo disposto no $\mathrm{CPC} / 2015^{16}$.

Interessante destacar que o CPC/2015, reproduziu, em certa dimensão, o modelo democratizante de processo vivenciado pela jurisdição constitucional (CATHARINA, 2019). Este modelo de processo decisório tem como principal característica uma pluralização do débito acerca do tema a ser julgado pela decisão paradigmática.

\section{CONSIDERAÇÕES FINAIS}

O principal objeto deste trabalho foi apresentar algumas notas sobre a necessária reformulação da teoria geral dos recursos em nosso ordenamento jurídico processual na vigência do CPC/2015. Esta reconstrução da teoria geral dos recursos passa por 03 (três) perspectivas de análise distintas mais complementares.

A conjugação de alguns elementos para se configurar uma teoria dos precedentes judiciais no Brasil é premente. Embora haja divergência doutrinária em relação à existente de um arcabouço normativo que justifique um sistema de precedentes judiciais, em nossa compreensão, é emergente a construção de uma teoria dos precedentes que, a partir de nossa cultura jurídica processual, contemplo os diversos modelos decisórios que concorrem em nosso direito processual civil. Com efeito, analisar, como categorias distintas, a jurisprudência uniformizadora, os provimentos jurisdicionais vinculantes e os precedentes judiciais, como

\footnotetext{
${ }^{16}$ Esta concepção de processo se aproxima da abordagem teórica levada a efeito por Marcelo Pereira de Almeida na obra Precedentes judiciais: análise crítica dos métodos empregados no Brasil para resolução das demandas de massa (2014).
} 
desdobramentos de um modelo processual complexo, é um passo significativo no que tange à efetivação do direito fundamental ao acesso à ordem jurídica justa.

Aprofundando o debate, a ressemantização do conceito de recurso e de ações autônomas de impugnação é fundamental para compreender a dimensão híbrida destes instrumentos processuais no modelo decisório disposto no CPC/2015. Neste novo contexto, um recurso ou mesmo uma ação autônoma de impugnação é suficiente para tutelar diferentes subjetivos e, ao mesmo tempo, contribuir para ampliar e aprimorar o sistema decisório vigente em nosso ordenamento processual.

Por fim, destaca-se que a reconstrução da teoria geral dos recursos, com forte ênfase na teoria da decisão judicial, não pode desconsiderar o pluralismo do debate e a democratização do processo decisório. Em sociedades complexas e desiguais não se pode estabelecer um modelo decisório vinculante sem assegurar um debate amplo e igualitário no processo de formação das decisões judiciais com ampla repercussão social, jurídica e política, como ocorre nas decisões judiciais com forte impacto no Brasil.

Pretendeu-se, neste trabalho, ratar de algumas notas ou apontamentos sobre a necessidade de se reconstruir a teoria geral dos recursos na vigência do CPC/2015. As notas ou propostas aqui apresentadas representam um convite ao debate sobre a temática, cujo emergência buscou-se destacar.

\section{REFERÊNCIAS BIBLIOGRÁFICAS}

ALMEIDA, Marcelo Pereira de. Precedentes judiciais: análise crítica dos métodos empregados no Brasil para resolução das demandas de massa. Curitiba: Juruá, 2014.

BRASIL. Superior Tribunal de Justiça. Reclamação $n^{o}$ 36.376-SP. Disponível em: https://ww2.stj.jus.br/jurisprudencia/externo/informativo/. Acesso em: 22 maio 2020.

BUSTAMANTE, Thomas da Rosa de. Teoria do precedente judicial: a justificação e aplicação das regras jurisprudenciais. São Paulo: Noeses, 2012.

CATHARINA, Alexandre de Castro. Jurisdição constitucional e processo civil democrático: um diálogo necessário para a construção de um paradigma decisório comum. Revista Direitos Humanos E Democracia,7(13), 300-312, julho/2019. https://doi.org/10.21527/23175389.2019.13.300-312. 
CATHARINA, Alexandre de Castro. Movimentos sociais e a construção dos precedentes judiciais. Curitiba: Juruá, 2015.

DUARTE, Fernanda; IORIO FILHO, Rafael. A impossibilidade da igualdade jurídica no Brasil. Revista Juris Poiesis. Rio de Janeiro, n. 14, p. 47-62, jan-dez/2011.

MARINONI, Luiz Guilherme. Precedentes Obrigatórios. São Paulo. Ed. Revistas dos Tribunais, 2010.

MARINONI, Luiz Guilherme. Julgamento nas cortes supremas: precedentes e decisão do recurso diante do novo CPC. 2. ed. São Paulo: Revistas dos Tribunais, 2017.

MEDINA, José Miguel Garcia. Direito Processual Civil Moderno. São Paulo: Revista dos Tribunais, 2015.

MENDES, Aluisio Gonçalves de Castro. Incidente de resolução de demandas repetitivas: sistematização, análise e interpretação do novo instituto processual. Rio de Janeiro: Forense, 2017.

MITIDIERO, Daniel. Precedentes judiciais: da persuasão à vinculação. São Paulo: Revista dos Tribunais, 2017.

NUNES, Dierle José Coelho. Processo jurisdicional democrático: uma análise crítica das reformas processuais. Curitiba: Juruá, 2012.

PINTO, Adriano Moura da Fonseca. Um olhar sobre as Decisões Monocráticas e Colegiadas, Fundamentação e uso de Precedentes do CPC 2015 no âmbito das Câmaras Cíveis do Tribunal de Justiça do Rio de Janeiro. Revista Juris Poiesis. Rio de Janeiro, v. 23, n. 32, p. 81-103, agosto/2020.

SILVA, Maria Inês de; DIAS, Luciana Drimel. O precedente como garantia da igualdade para as decisões judiciais. Revista Eletrônica de Direito Processual da UERJ, Rio de Janeiro, RJ, v. 21, n. 1, p. 294-311, janeiro. 2020. ISSN 1982-7636. Disponível em: < https://www.epublicacoes.uerj.br/index.php/redp/article/view/45320/31776>. Acesso em: 22 maio. 2020.

SOARES, Marcelo Negri; COUTO, Monica Bonetti; COSTA, Jessica Chaves. Dever de fundamentação e precedentes judiciais no novo CPC: uma análise à luz do modelo constitucional de processo. Revista Eletrônica do Curso de Direito da UFSM, Santa Maria, RS, v. 13, n. 2, p. 554-576, ago. 2018. ISSN 1981-3694. Disponível em: <https://periodicos.ufsm.br/revistadireito/article/view/29302>. Acesso em: 22 maio 2020. doi:http://dx.doi.org/10.5902/1981369429302.

STRECK, Lenio Luiz; ABBOUD, Georges. O que é isto - o sistema (sic) de precedentes no CPC? In: Revista Consultor Jurídico, 18 de agosto de 2016. Disponível em <>. Acesso em: 25/08/2018.

THEODORO JUNIOR, Humberto. NUNES, Dierle. BAHIA, Alexandre Melo Franco. PEDRON, Flavio Quinaud. Novo CPC - Fundamentos e sistematização. Rio de Janeiro: Forense, 2015. 
ZUFELATO, Camilo; PINHEIRO DIAS, Caio Gracco. Ação rescisória em face de acórdão que extinguiu ação coletiva, com fundamento em violação à norma jurídica: análise segundo os precedentes judiciais dos tribunais superiores em torno do tema da legitimidade ativa das associações civis. Revista Eletrônica de Direito Processual da UERJ, Rio de Janeiro, RJ, v. 21, n. 2, p. 20-44, maio. 2020. ISSN 1982-7636. Disponível em: < https://www.epublicacoes.uerj.br/index.php/redp/article/view/46861/33404>. Acesso em: 22 maio. 2020.

Data de Submissão: 30/09/2020

Data de Aceite: 18/12/2020 